Research Article

\title{
Ecophysiology, genotoxicity, histopathology, and gene responses of naphthalene injected Colossoma macropomum (Cuvier, 1818) exposed to hypoxia
}

\author{
Samara Silva de Souza ${ }^{1}$ (D) , Grazyelle Sebrenski da Silva ${ }^{1,2}$ iD and Vera Maria Fonseca de Almeida-Val ${ }^{1}$ (D) \\ ${ }^{1}$ Laboratory of Ecophysiology and Molecular Evolution, National Institute for Research in the Amazon \\ (INPA), Manaus, AM, Brazil. \\ ${ }^{2}$ Institute of Biological Science (ICB), Universidade Federal do Amazonas (UFAM), Manaus, AM, Brazil.
}

\begin{abstract}
The present study aimed to evaluate the biological responses of Colossoma macropomum to naphthalene injection and subsequent hypoxia exposure, emphasizing the expression of the tumor suppressor gene tp53. Tambaquis were intraperitoneally injected with naphthalene $(50 \mathrm{mg} / \mathrm{kg})$ and, after 96 hours, the fish were transferred to respirometry chambers and, submitted to progressive hypoxia for the determination of critical $\mathrm{PO}_{2}$. In a subsequent experiment, the fish received an intraperitoneal injection of naphthalene and were kept for 96 hours under normoxia. Successively, fish were challenged with acute hypoxia $\left(\mathrm{PO}_{2}<\mathrm{PO}_{2}\right.$ crit) during 6 hours. We observed that the $\mathrm{PO}_{2}$ crit was not affected by naphthalene injection. Moreover, hematological parameters were modulated only in response to hypoxia. Fish with naphthalene injection plus hypoxia exposure presented altered activity of the GST and CAT enzymes. Exposure to naphthalene also resulted in DNA damages, which was not influenced by hypoxia. Hypoxia accentuated the hepatic lesions caused by naphthalene, as well as it also impaired the transcription of $t p 53$ in naphtalene injected fish, demonstrating the risks of contaminating aquatic environments, especially environments where hypoxic conditions are common and occur on a daily or on seasonal basis, as in the Amazon basin.
\end{abstract}

Keywords: Naphthalene, hypoxia, tumor suppressor gene tp53, DNA damage, tambaqui.

Received: March 28, 2018; Accepted: August 01, 2018.

\section{Introduction}

Several sources of aquatic pollution, including the presence of highly toxic polycyclic aromatic hydrocarbons (PAHs) affect aquatic organisms (Palanikumar et al., 2013; Kochhan et al., 2015; Sadauskas-Henrique et al., 2017). Among PAHs, naphthalene stands out as one of the main constituents of crude oil (Negreiros et al., 2011; Gusmão et al., 2012; Omar-Ali et al., 2015). Naphthalene toxicity is the result of the biotransformation process, which consists in cellular chemical reactions with the aim of making the compounds more soluble in water, facilitating their excretion. During biotransformation, besides the generation of more toxic intermediate compounds, the formation of reactive oxygen species (ROS) can occur. ROS are unstable molecules capable of inducing oxidative stress (Van der Oost et al., 2003; Shi et al., 2005) and several damages to the animal cells. ROS can interact with biological macromolecules inducing damage to proteins, lipids, and DNA

Send correspondence to Vera Maria Fonseca de Almeida-Val. Laboratory of Ecophysiology and Molecular Evolution, National Institute for Research in the Amazon (INPA), Av. André Araújo, Petropólis, 2936 69067-375 Manaus, AM, Brazil. E-mail: veraval30@gmail.com
(Van der Oost et al., 2003). Several studies demonstrated that the presence of naphthalene and other PAHs can result in increases in the activity of antioxidant enzymes involved in the neutralization of ROS, as well as increased DNA damages and lipid peroxidation in the gills and liver of fish (Shi et al., 2005; Palanikumar et al., 2013; SadauskasHenrique et al., 2017).

Damages caused by ROS can compromise the function of different tissues. Kochhann et al. (2015) observed the occurrence of gill damage in Colossoma macropomum exposed to crude oil. Such damages promote an increase in the diffusion barrier to reduce the contact between tissue and pollutant; however, they compromise tissue function, including oxygen uptake. Silva et al. (2017) demonstrated that the intraperitoneal injection of different benzo[a]pyrene (BaP) concentrations in C. macropomum resulted in the occurrence of irreparable histopathological damages in the liver, which may be directly related to the damages caused by ROS produced during the biotransformation of this PAH. The histopathological damages resulting from exposure to $\mathrm{BaP}$ reflect on the molecular responses of the species, since the exposure of those fish to $\mathrm{BaP}$ also affected the expression of genes related to the de- 
velopment of cancer, such as the oncogene ras and the gene hif-1 $\alpha$ (Silva et al., 2017).

In the Amazon basin, the effects of contamination by PAHs, such as naphthalene, can be more drastic, since its aquatic environments have particular characteristics, including seasonal and daily variations in the concentration of dissolved oxygen in water (Junk et al., 1983; Val and Almeida-Val, 1995). Several studies have evaluated the effects of PAHs and hypoxia independently. However, the interaction between the two factors has been little explored in freshwater organisms. Fish studies demonstrated that exposure to hypoxia accentuates the negative effects of stressors such as ultraviolet radiation and crude oil, affecting the detoxification process and antioxidant defenses, as well as accentuating DNA and histopathological damages (Negreiros et al., 2011; Dasgupta et al., 2016; Groff et al., 2010; Silva et al., 2019). The combination of hypoxia and contaminants also affects the expression of genes involved in carcinogenesis. Silva et al. (2019) demonstrated that exposure of C. macropomum to Roundup ${ }^{\circledR}$ herbicide and subsequent exposure to hypoxia resulted in down-regulation of ras oncogene expression.

Hypoxia plays an essential role in cell proliferation, angiogenesis, tumor progression, and metastasis. Hypoxia is toxic to cells. However, cancer cells survive and proliferate in a hypoxic environment, which contributes to the malignant phenotype and aggressive tumor behavior (Vaupel and Mayer, 2007; Lee et al., 2009; Eales et al., 2016). Both factors naphthalene and hypoxia, can modulate the expression of genes involved in cell cycle control and DNA repair, such as the tumor suppressor gene tp 53, once this gene expression is influenced by the occurrence of DNA damage (Kastan et al., 1991; Park et al., 2006). As a transcription factor, the p 53 protein, encoded by the tp 53 gene, is critical in the maintenance of genomic integrity. The $\mathrm{p} 53$ protein is also involved in the restriction of neoplastic progression in mammals (Donehower et al., 1992) and fish (Berghmans et al., 2005; Tu et al., 2016). Studies report that fish captured at contaminated sites or exposed to xenobiotics show increased levels of tp53 mRNA (Mai et al., 2012; Ruiz et al., 2012; Williams and Hubberstey, 2014). Hypoxia also regulates $t p 53$. Most studies with $t p 53$ are performed using mammalian cells in vitro (Koumenis et al., 2001; Hammond et al., 2002; Cosse et al., 2009; Chen et al., 2010). In vivo, hypoxia may either increase or decrease the $t p 53$ transcription in the white shrimp (Litopenaeus vannamei) depending on the tissue type (Felix-Portillo et al., 2016; Nuñez-Hernandez et al., 2018).

Fish are regularly exposed to several contaminants in the aquatic environment, making them more susceptible to damage caused by pollutants. In the Amazon basin, Colossoma macropomum has been widely used as a bioindicator in toxicological studies of aquatic contamination by crude oil and petroleum derivated products (Duarte et al., 2010; Kochhann et al., 2013, 2015; Sadauskas-Henrique et al., 2016, 2017; Silva et al., 2017). These preliminary studies demonstrate that tambaqui is a good model for ecotoxicological studies, including for analysis of gene expression related to the development of cancer, since it is able to resist to different environmental contaminants, as well as to the combination between contaminants and changes in water quality, such as variations in dissolved oxygen concentrations, a common factor in Amazonian aquatic environments (Val and Almeida-Val, 1995; Kochhann et al., 2013, 2015; Sadauskas-Henrique et al., 2016, 2017; Silva et al., 2017; Silva et al., 2019). Analysis of tp53 gene expression combined with antioxidant responses and damage resulting from exposure to naphthalene in a species with adaptations that allow them to survive in hypoxic environments can provide information on molecular mechanisms that allow survival of the species under stress conditions. Thus, this work aimed to investigate the tumor suppressor tp53 gene expression after naphthalene injection and subsequent exposure to acute hypoxia. To verify the oxidative stress and damages, we analyzed changes in antioxidant and biotransformation enzymes, as well as DNA and histopathological damages in the liver of C. macropomum.

\section{Material and Methods}

\section{Experimental fish}

Tambaqui juveniles (Colossoma macropomum) were purchased from a local fish farm (Fazenda Santo Antônio: 02 $44^{\prime} 802^{\prime \prime}$ S; 059 28'836''W, Amazonas, Brazil) and transferred to the Laboratory of Ecophysiology and Molecular Evolution at INPA (National Institute for Research in the Amazon, Manaus, Amazonas). Animals were firstly acclimated outdoors for 60 days in 3000-L polyethylene aerated tanks with constant water circulation. During the acclimation period, fish were fed daily until satiation with commercial pelleted food (36\% protein, Nutripeixe-Purina). Feeding was suspended 24 hours before the beginning of the experiments. All experimental procedures followed CONCEA Brazilian Guidelines for Animals Use and Care, under INPAs authorization by the Committee of Ethics for Use of Animals (CEUA protocol number 043/2015). All fish used in the present study were sexually immature.

\section{Experiment 1: Determination of critical oxygen tension}

The first experiment was performed only to determine the critical oxygen tension $\left(\mathrm{PO}_{2}\right.$ crit) and define the oxygen concentration to be used in the experiments under hypoxic conditions (Experiment 2). The $\mathrm{PO}_{2}$ crit is the partial oxygen tension below which the availability of oxygen becomes insufficient for the regulation of the metabolic rate of the organism and, the animal starts to conform to the tension of oxygen, modifying its respiration rate according to the environmental $\mathrm{PO}_{2}$ (Pörtner et al., 1985). Five individuals per treatment, with $27.9 \pm 6.8 \mathrm{~g}$ body mass and 10.9 
$\pm 1.2 \mathrm{~cm}$ length (mean \pm standard deviation), were acclimated for 48 hours before the start of the experiments. They were divided into three treatments and individually placed in $3 \mathrm{~L}$ glass aquaria. In the first treatment, the fish did not receive the injection (group without injection - GWI). In the second treatment (Sham) fish were injected with the vehicle solution (corn oil Sigma ${ }^{\circledR}$ ). In the third treatment (Naph) fish were injected with the solution containing naphthalene dissolved in corn oil. Naphthalene was administered to fish via intraperitoneal (i.p) injection based on the body weight of each fish. Before injections, all animals were anesthetized in water at $10^{\circ} \mathrm{C}$ for $30 \mathrm{~s}$ and were then weighed and measured. The individuals of the Naph group all received the same dosage $(50 \mathrm{mg} / \mathrm{kg})$. This naphthalene concentration used in the present study was determined from other studies where the authors used the same route of administration (Tintos et al., 2007; Gesto et al., 2009).

Fish were returned to their aquarium after the injection, and after 96 hours they were individually transferred to respirometry chambers $(1.7 \mathrm{~L})$ inside a bath aquarium and maintained for 1 hour in a recirculating system with continuous water flush. The control of the recirculation cycle was done by AutoResp software (Loligo System). The amount of oxygen in the chambers was measured using OXY-4 and Witrox-4 (Loligo System) oximeters. Then, the flow phase was stopped, and the fish were exposed to progressive hypoxia so that the decrease in $\mathrm{PO}_{2}$ occurred as the oxygen available inside the chambers was being consumed. Subsequently, the oxygen consumption rates were calculated, and $\mathrm{PO}_{2}$ crit was determined using the SegReg program (www.waterlog.info). The methodology was the same as the one used by Campos et al. (2016).

\section{Experiment 2: Naphthalene contamination and subsequent exposure to hypoxia}

Tambaqui juveniles $(58.8 \pm 6.3 \mathrm{~g}$ and $14.0 \pm 0.5 \mathrm{~cm})$ were divided into three treatments, six individuals for each treatment, and separated into glass aquaria where they were maintained for 48 hours before the beginning of experiments. In the first treatment (group GWI), the fish received no intraperitoneal injection. In the second treatment (group Sham), the fish received corn oil, and in the third treatment, the fish received naphthalene dissolved in corn oil (group Naph). Fish from group Naph were injected intraperitoneally with $50 \mathrm{mg} / \mathrm{kg}$ of naphthalene using corn oil as vehicle. The injections occurred as described above. After injections, fish were returned to their glass aquaria and kept under constant temperature, aeration, and $\mathrm{pH}$ (temperature $=27.04{ }^{\circ} \mathrm{C} \pm 0.79$; oxygen $=6.0 \pm 0.25 \mathrm{mg} \mathrm{O} . \mathrm{L}^{-1} ; \mathrm{pH}=7.2$ \pm 0.55 - mean \pm standard deviation) for 96 hours. After 96 hours, the $\mathrm{PO}_{2}$ for fish in the hypoxia groups was decreased slowly by pumping $\mathrm{N}_{2}$ gas directly into the water, and the animals were kept for six hours under acute hypoxia, at $1.08 \pm 0.10 \mathrm{mg} \mathrm{O}_{2} \cdot \mathrm{L}^{-1}$. The normoxia groups were kept in the respective aquaria for the same six hours under constant aeration at $6.07 \pm 0.25 \mathrm{mg} \mathrm{O} \cdot \mathrm{L}^{-1}$. At the end of each experiment, blood samples were immediately drawn from the caudal vein into heparinized syringes. Blood was used in the hematological analysis and comet assay. After blood sampling, fish euthanasia occurred by a concussion to their heads, followed by an immediate cut in the spinal cord. Then, the liver was excised and stored at $-80^{\circ} \mathrm{C}$ until analysis. Liver was used in the analysis of the activity of GST and CAT, LPO, histopathological damage, and gene expression.

\section{Hematological assays}

For hematocrit determination (Hct) blood samples were transferred to microhematocrit capillaries and centrifuged at 12,000 rpm (Centrifuge 3400, FANEM) for 10 minutes. Reading of the percentage of sedimentation (\%) was performed using a standard scale (Goldenfarb et al., 1971). Hemoglobin ([Hb]) concentration was determined spectrophotometrically at $540 \mathrm{~nm}$ according to the cyanmethemoglobin method (Kampen and Zijlstra, 1961). Red blood cell (RBC) counts were done in a Neubauer chamber. The corpuscular constants were calculated according to Brown (1976). Plasma was obtained after blood centrifugation at $604 \mathrm{~g}$ for 10 minutes for glucose analysis. Plasma glucose was determined using the Glucose Liquicolor Kit (InVitro $\left.{ }^{\circledR}\right)$.

\section{Biochemical Analysis}

Liver samples were homogenized in cold buffer solution $(200 \mathrm{mM}$ Tris-Base, $1 \mathrm{mM}$ EDTA, $1 \mathrm{mM}$ dithiothreitol, $500 \mathrm{mM}$ sucrose, $150 \mathrm{mM} \mathrm{KCL}, \mathrm{pH}$ 7.6) and centrifuged at $9,000 \mathrm{x}$ for $30 \mathrm{~min}$ at $4{ }^{\circ} \mathrm{C}$. The supernatant was used to analyze glutathione S-transferase (GST) and catalase (CAT) activity. To determine the extent of lipid peroxidation (LPO), liver samples were weighed, homogenized $(1: 2 \mathrm{w} / \mathrm{v})$ in the same buffer as used for GST and CAT, and centrifuged at $1,062 \mathrm{xg}$ for $10 \mathrm{~min}$ at $4{ }^{\circ} \mathrm{C}$. GST activity was determined as described by Keen et al. (1976) using CDNB (1-chloro-2,4-dinitrobenzene) as a substrate.Absorbance was measured spectrophotometrically at $340 \mathrm{~nm}$, and GST activity was calculated as nmol CDNB conjugate $/ \mathrm{min} / \mathrm{mg}$ protein. The determination of CAT activity was done according to the methodology described by Beutler (1975), which consists of measuring the rate of degradation of hydrogen peroxide $\left(\mathrm{H}_{2} \mathrm{O}_{2}\right)$ at $240 \mathrm{~nm}$. CAT activity was expressed in $\mu \mathrm{mol} \mathrm{H}_{2} \mathrm{O}_{2} \mathrm{~min} / \mathrm{mg}$ protein. $\mathrm{LPO}$ in the liver was quantified spectrophotometrically at $560 \mathrm{~nm}$ by the Ferrous Oxidation/Xylenol Orange method, as described by Jiang et al. (1992). The LPO concentration was expressed in $\mu \mathrm{M}$ of CHP (Cumene hydroperoxide) / $\mathrm{mg}$ protein.

\section{Protein determination}

Total protein in the liver extracts used for the enzyme analyses was measured spectrophotometrically at $595 \mathrm{~nm}$ 
according to the method described by Bradford (1976), using bovine serum albumin as standard.

\section{Comet assay}

The comet assay was performed in alkaline conditions, as described by Singh et al. (1988) for lymphocytes and modified by Silva et al. (2000) for peripheral blood cells. Diluted blood with cell suspension was mixed with low melting point agarose $0.75 \%$ (Gibco BRL) and spread on the slides pre-covered with normal melting agarose $(1.5 \%)$ prepared in phosphate-buffered saline (PBS). The slides were placed in a cold lysing solution. After fixation, the slides were placed in an electrophoresis chamber and submerged in freshly prepared alkaline buffer ( $\mathrm{pH} 13.0)$ for 20 min before; a current $25 \mathrm{~V}$ was applied for $15 \mathrm{~min}$. Subsequently, the slides were washed with $0.4 \mathrm{M}$ Tris buffer (pH 7.5) and stained with silver solution for $15 \mathrm{~min}$ at 37 ${ }^{\circ} \mathrm{C}$. Using an optical microscope (Leica DM205) at $100 \mathrm{x}$ magnification, 100 cells were analyzed from each of two replicate slides randomly selected from each fish. The damage was visually classified into five classes according to tail size. Counting was performed observing the tail size formed due to migration of damaged DNA after electrophoresis. Class 0 corresponds to intact DNA, without tail; class 1, low damage index; class 2, intermediate damage; class 3, high damage; and class 4, extreme damage. Figure 1 illustrates the different damage classes that occurred in the present work. The genetic damage index (GDI) for each fish was calculated as the number of cells observed in each damage class multiplied by the value of the class damage according to the following formula:

$$
\mathrm{DGI}=(\mathrm{Ax} 0)+(\mathrm{Bx} 1)+(\mathrm{Cx} 2)+(\mathrm{Dx} 3)+(\mathrm{Ex} 4)
$$

(Kobayashi et al., 1995), where: $\mathrm{A}=$ total cells without damage; $\mathrm{B}=$ total cells with damages class $1 ; \mathrm{C}=$ total cells with damages class $2 ; \mathrm{D}=$ total cells damges class 3 ; and $\mathrm{E}=$ total cells damages class 4 .

\section{Liver histopathological analysis}

Liver samples $(\mathrm{n}=6)$ were fixed in ALFAC solution ( $80 \%$ ethanol, $5 \%$ glacial acetic acid, and $4 \%$ formaldehyde) for 15 hours and transferred to $70 \%$ ethanol. Subsequently, tissues were dehydrated in successive ethanol baths, diaphanized in xylol, and included in paraffin.
Blocks were sliced in $5 \mu \mathrm{m}$ thick sections, stained with hematoxylin-eosin (HE) and read by light microscopy (Leica DM2015) at 40x. Two sections of liver lesions were qualitatively analyzed for each fish using the levels classified by Poleksic and Mitrovic-Tutundic (1994), modified by Silva (2004). The carbohydrate stainning histochemistry was applied for the evaluation of hepatic glycogen, using the PAS method (Periodic Acid Schiff).

\section{Total RNA extraction and first-strand (cDNA) synthesis}

Total RNA was extracted from liver $(\mathrm{n}=4$, for each treatment) using Trizol Reagent (InvitrogenTM, Life Technologies). The concentration and purity of total RNA samples were checked in a NanoDrop ${ }^{\circledR} 2000$ Spectrophotometer (Thermo Scientific). RNA integrity was verified by an electrophoretic run in an agarose gel $(2 \%)$. Possible residues of genomic DNA were removed by the DNase I kit (Invitrogen, Life Technologies). cDNA synthesis was performed using the Platus Transcriber RNase H cDNA First Strand kit (Sinpase Inc.) following the manufacturer's instructions.

\section{Sequencing and primer obtention}

Primers for the $t p 53$ gene (forward: ${ }^{5}$ GGAGTGGC TGATTCAGAG ${ }^{3}$; reverse: ${ }^{5}$ 'TTAAGGAGAGCGGTC $\mathrm{ATG}^{3}$; efficience: $100.24 \% ; \mathrm{R}^{2}: 0.98$ ) were designed from sequences obtained from the tambaqui transcriptome (Prado-Lima and Val, 2016) (Access number: SRP062336). Sequences of the $t p 53$ gene were validated using the BLASTn tool in NCBI (http://www.ncbi.nlm.nih.gov). Primers were designed in Oligo Explorer 1.1.2 software. For normalization of target gene expression, two housekeeping genes were used: ribosomal gene $28 S$ (forward: ${ }^{\circ}$ CGGGTTCGTTTGCG TTAC $^{3}$; ; reverse: ${ }^{5}$ AAAGGGTGTCGGGTTCAGAT ${ }^{3}$; efficience: $\left.98.19 ; \mathrm{R}^{2}: 0.99\right)$ and transcription elongation factor ef- $1 \alpha$ (forward: ${ }^{5}$ 'GTTGGTGAGTTTGAGGCT $\mathrm{GG}^{3}$; reverse: ${ }^{5}$ CACTCCCAGGGTGAAAGC ${ }^{3}$; efficience: $99.09 ; \mathrm{R}^{2}: 0.99$ ). These genes were used in prior studies with both exposures to PAH and hypoxia, showing stable expression (Silva et al., 2017; Silva et al., 2019).
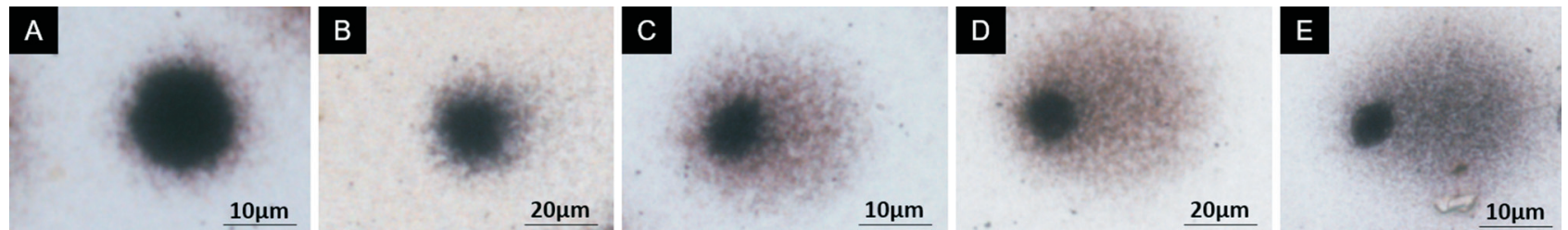

Figure 1 - Class of DNA damages (comet assay) observed in blood cells of C. macropomum in the three experimental groups: Group Without Injection (GWI), Group with corn oil injection (Sham); and Group with naphthalene injection (Naph) after $96 \mathrm{~h}$ normoxia exposure followed by $6 \mathrm{~h}$ of hypoxia. Class 0 , without damages (A), class 1 (B), class 2 (C), class 3 (D), and class 4, maximum damages (E). The images were captured with $400 \mathrm{x}$ magnication. 


\section{Quantitative real-time (qPCR) analysis}

qPCR reactions were performed in a Viia 7 Dx PCRSystem (Applied Biosystem). Each reaction was performed in triplicate with $1000 \mathrm{ng}$ cDNA using Fast $\mathrm{SYBR}^{\circledR}$ Green PCR Master Mix (Applied Biosystems). The reaction condition was: heating for $2 \mathrm{~min}$ at $50^{\circ} \mathrm{C}$ and $95^{\circ} \mathrm{C}$ for $10 \mathrm{~min}$, followed by 40 cycles of $95^{\circ} \mathrm{C}$ for $15 \mathrm{~s}$ and $60^{\circ} \mathrm{C}$ for $1 \mathrm{~min}$ (annealing temperature of all primers). Differences in gene expression were calculated using the method $2^{-\Delta \Delta \mathrm{Ct}}$ (Livak and Schmittgen, 2001).

\section{Statistical analysis}

Data are expressed as the mean \pm standard error of the mean (mean \pm SEM). Prior to comparative statistical analyses, data were assessed for normality and homogeneity of variance. A one-way analysis of variance (ANOVA) was applied to verify differences in the critical oxygen tension $\left(\mathrm{PO}_{2}\right.$ crit). A two-way ANOVA was applied in the analysis of hematological parameters $([\mathrm{Hb}]$, Hct, RBC, MCV, $\mathrm{MCH}, \mathrm{MCHC}$, and plasma glucose), GST and CAT activity, LPO, comet assay, and gene expression, using oxygen concentration and treatments as factors. Significant differences between the means were scored by the Tukey test, at the 5\% level of significance. A principal component analysis (PCA) was performed to verify whether the clustering of the analyzed variables was determined mainly by the naphthalene injection or by the oxygen concentration. The statistical tests were run using SigmaStat 3.5 and Statistica 7.0 programs.

\section{Results}

\section{Critical oxygen tension}

No difference was detected in the critical oxygen tension $\left(\mathrm{PO}_{2}\right.$ crit) for C. macropomum among treatments $(p=0.825 ; \mathrm{F}=0.195)$. The critical oxygen tensions were 1.56 $\pm 0.12,1.66 \pm 0.13$ and $1.56 \pm 0.14 \mathrm{mg} \mathrm{O}_{2} . \mathrm{L}^{-1}$ for the GWI, Sham, and Naph groups, respectively. The metabolic rate at reduced levels of dissolved oxygen in water decreased in the same way in fish from all three treatments, demonstrat- ing that naphthalene did not affect the oxygen consumption of C. macropomum.

\section{Hematological parameters}

Interestingly, no differences were detected in hematological parameters in fish of the three treatments (GWI; Sham; and Naph) at normoxia (Table 1). Conversely, hypoxia affected some hematological parameters in fish priorly exposed to GWI, Sham and Naph groups; hemoglobin concentration increased in the Sham and Naph groups in hypoxia compared to normoxia $(p<0.05 ; \mathrm{F}=16.261)$. There was an increase in hematocrit $(p<0.001 ; \mathrm{F}=84.712)$, in $\operatorname{RBC}(p<0.05 ; \mathrm{F}=28.825)$, and there was a decrease in MCHC $(p<0.05 ; \mathrm{F}=25.870)$ in fish kept under hypoxia when compared to the same groups in normoxia. The lower oxygen concentration also influenced plasma glucose levels in fish of all treatments $(p<0.001 ; \mathrm{F}=57.404)$, resulting in the increase of this metabolite under hypoxic conditions compared to normoxia $(p<0.05)$, with no differences, however, as above mentioned among the three treatments in each condition: normoxia or hypoxia.

\section{Biochemical analysis}

Hepatic GST activity was influenced by the Naph injection ( $p=0.038 ; \mathrm{F}=3.659)$, but there was no influence of hypoxia $(p=0.113 ; \mathrm{F}=2.675)$, or interaction between the factors $(p=0.112 ; \mathrm{F}=2.366)$. GST activity decreased 1.4 fold in fish injected with naphthalene $(p<0.05)$ compared to the GWI in normoxia. There were no differences among the three treatments under hypoxia. However, fish that received Naph injection and were subsequently exposed to hypoxia showed a 1.4 fold increase in GST activity compared to those remaining under normoxia $(p<0.05)$. There were no differences between GWI and Sham in both normoxia and hypoxia groups (Figure 2A).

Hepatic CAT activity was influenced by Naph $(p=$ $0.002 ; \mathrm{F}=7.513$ ) compared to GWI and Sham groups; however, there was no influence of hypoxia $(p=0.254 ; \mathrm{F}=$ $1.351)$ or interaction between the factors $(p=0.052 ; \mathrm{F}=$ 3.267). Enzyme activity decreased 1.2 fold in fish contami-

Table 1 - Hematological parameters levels in C. macropomum in the groups without injection (GWI), with corn oil injection (Sham) and naphthalene injection (Naph) after $96 \mathrm{~h}$ to normoxia exposure followed by $6 \mathrm{~h}$ of hypoxia. *Indicates statistical difference between normoxia and hypoxia of the same treatment. Significance value $p<0.05$.

\begin{tabular}{|c|c|c|c|c|c|c|}
\hline \multirow[b]{2}{*}{ Parameter } & \multicolumn{2}{|c|}{ GWI } & \multicolumn{2}{|c|}{ Sham } & \multicolumn{2}{|c|}{ Naph } \\
\hline & Normoxia & Hypoxia & Normoxia & Hypoxia & Normoxia & Hypoxia \\
\hline Het $(\%)$ & $21 \pm 0.43$ & $28.7 \pm 1.16^{*}$ & $20.2 \pm 1.17$ & $28 \pm 1.18^{*}$ & $21.6 \pm 1.01$ & $27.8 \pm 0.49 *$ \\
\hline $\mathrm{Hb}(\mathrm{g} / \mathrm{dL})$ & $8.9 \pm 0.25$ & $9.3 \pm 0.73$ & $8.6 \pm 0.32$ & $10.5 \pm 0.28 *$ & $8.9 \pm 0.28$ & $10.2 \pm 0.12 *$ \\
\hline $\mathrm{RBC}\left(\times 10^{6} / \mathrm{mm}^{3}\right)$ & $1.5 \pm 0.09$ & $1.7 \pm 0.04 *$ & $1.4 \pm 0.05$ & $1.77 \pm 0.07 *$ & $1.5 \pm 0.09$ & $1.8 \pm 0.04 *$ \\
\hline $\operatorname{MCV}\left(\mu \mathrm{m}^{-3}\right)$ & $154 \pm 4.03$ & $164.6 \pm 5.35$ & $150.1 \pm 5.76$ & $152.5 \pm 3.71$ & $140.2 \pm 4.25$ & $149.6 \pm 5.48$ \\
\hline $\mathrm{MCH}(\mathrm{pg})$ & $59.9 \pm 2.64$ & $55 \pm 3.09$ & $64.2 \pm 3.09$ & $58.6 \pm 2.73$ & $65.7 \pm 4.23$ & $57.4 \pm 0.62$ \\
\hline $\mathrm{MCHC}(\%)$ & $41.2 \pm 0.96$ & $34.5 \pm 2.14 *$ & $44.0 \pm 1.18$ & $36.9 \pm 0.93 *$ & $42.1 \pm 2.21$ & $37.0 \pm 1.07 *$ \\
\hline Glucose (mg/dl) & $49.8 \pm 4.57$ & $84.1 \pm 9.27^{*}$ & $41.6 \pm 3.45$ & $87.5 \pm 8.28 *$ & $43.4 \pm 6.20$ & $96.4 \pm 9.08 *$ \\
\hline
\end{tabular}


nated with Naph $(p<0.05)$ compared to the GWI and Sham in normoxia. No differences between treatments were observed in fish groups under hypoxia. An increase in CAT activity occured in fish contaminated with naphthalene and later exposed to hypoxia in comparison to fish that remained in normoxia $(p<0.05)$. There were no differences between GWI and Sham in both normoxia and hypoxia groups (Figure 2B). Moreover, lipid peroxidation in the liver presented no differences among all treatments in both normoxia and hypoxia fish groups (Figure 2C).

\section{Genotoxic damage}

Injection with Naph resulted in the increase in the genetic damage index (GDI) in blood cells ( $p<0.05$; $\mathrm{F}=$ $19.259)$. The exposure to hypoxia did not increase these damages $(p=0.845, \mathrm{~F}=0.0388)$ and there was no interaction between the factors $(p=0.228 ; \mathrm{F}=1.556)$. Increases in DNA damage of 1.4 and 1.25 fold $(p<0.05)$ were observed in normoxic $C$. macropomum treated with Naph compared to the GWI and Sham groups, respectively. In hypoxic fish injected with Naph, the increase in DNA damage was 1.45 fold higher $(p<0.001)$ compared to GWI and Sham. No difference between normoxic and hypoxic fish groups was observed (Figure 3). With regard to DNA damage levels in blood cells, fish of the GWI and Sham groups, both in normoxia and hypoxia, presented a prevalence of damages class 1 , where, out of the 100 cells analyzed for GWI, 54.2 and $59.8 \%$ were characterized as class 1 in normoxia and hypoxia, respectively. For the Sham group, class 1 appeared in 48.7 , and $51.4 \%$ of cells in fish kept both under normoxia and hypoxia, respectively. The DNA damage class 2 was predominant in fish injected with Naph, being $47,2 \%$ for fish kept in normoxia and $53.5 \%$ after hypoxia exposure. DNA damage class 3 occurred in $7 \%$ of fish cells contaminated with Naph in the groups maintained in normoxia and hypoxia (Figure 3).
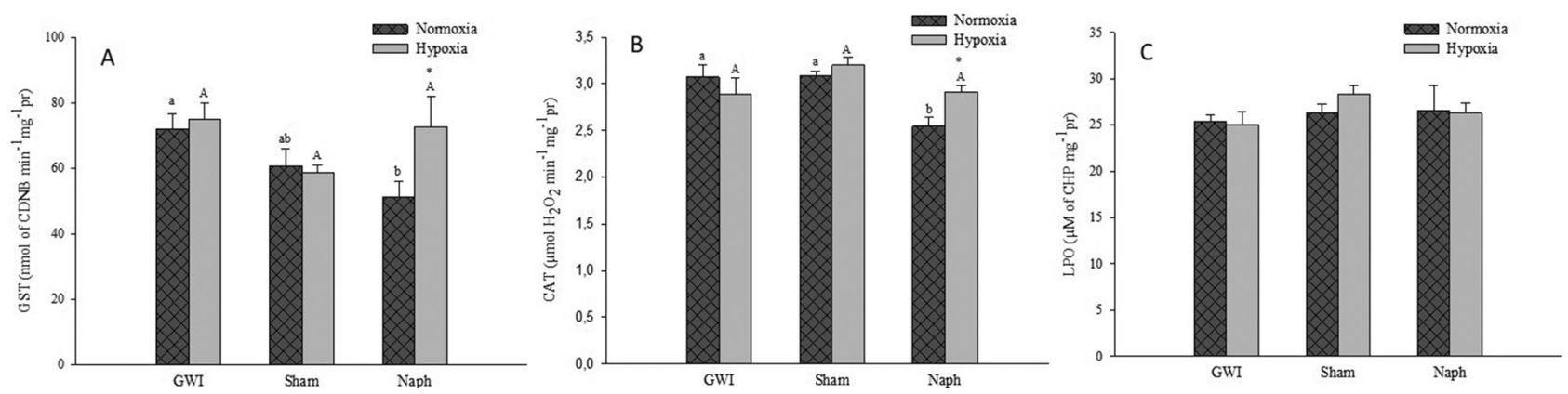

Figure 2 - GST (A) and CAT (B) activity and lipoperoxidation (LPO) (C) in the liver of C. macropomum in the three experimental groups: Group Without Injection (GWI), Group with corn oil injection (Sham); and Group with naphthalene injection (Naph) after $96 \mathrm{~h}$ normoxia exposure followed by $6 \mathrm{~h}$ of hypoxia. Small caps letters ( $\mathrm{a}$ and $\mathrm{b}$ ) indicate differences among treatments in normoxia. Capital letters (A and B) indicate differences among treatments in hypoxia. *Indicates differences between normoxia and hypoxia at the same treatment. Significance level of the Tukey test was $p<0.05$.

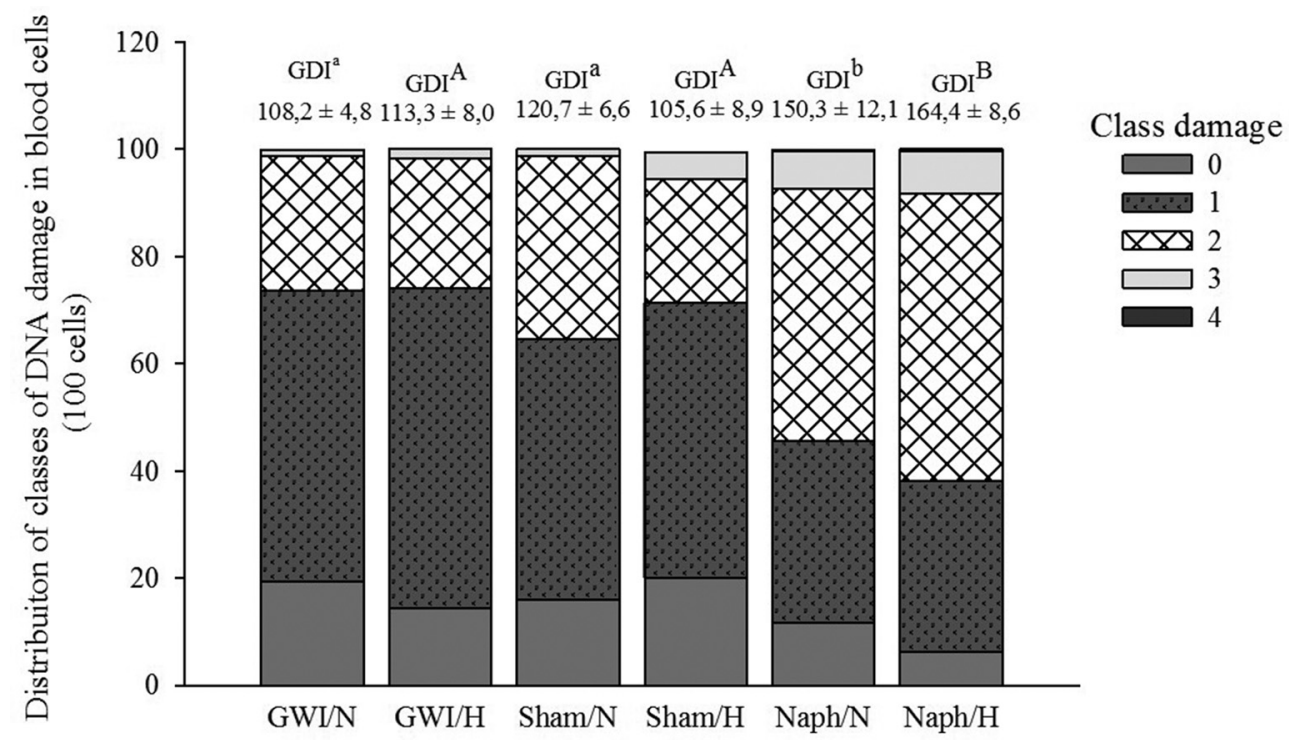

Figure 3 - Distribution of classes of DNA damage in C. macropomum blood cells in the three experimental groups: Group Without Injection (GWI); Group with corn oil injection (Sham); and Group naphthalene injection (Naph) after $96 \mathrm{~h}$ normoxia exposure (N) followed by $6 \mathrm{~h}$ of hypoxia (H). The Genetic Damage Index (GDI) is identified in each treatment (on the bars). Small cap letters (a and b) indicate statistical difference among treatments in normoxia. Capital letters (A and B) indicate statistical difference among hypoxia treatments. The statistical significance value was $p<0.05$. 


\section{Liver histopathology}

Healthy C. macropomum liver, similarly to other fish species, presented a parenchyma consisting of well delimited polyhedral hepatocytes, organized in linear cords surrounded by sinusoid capillaries as observed in the group without injection (GWI) (Figure 4A). In relation to qualitative analysis, most of the hepatic alterations noted in all treatments presented frequency ranging from rare to low, classified as mild or punctually localized (Table 2). Among stage I, nuclear hypertrophy ranged from frequent to highly frequent in fish treated with Naph under normoxic conditions (Figure 4B) and, in all hypoxia treatments. Cell deformation was a frequent change only in fish injected with

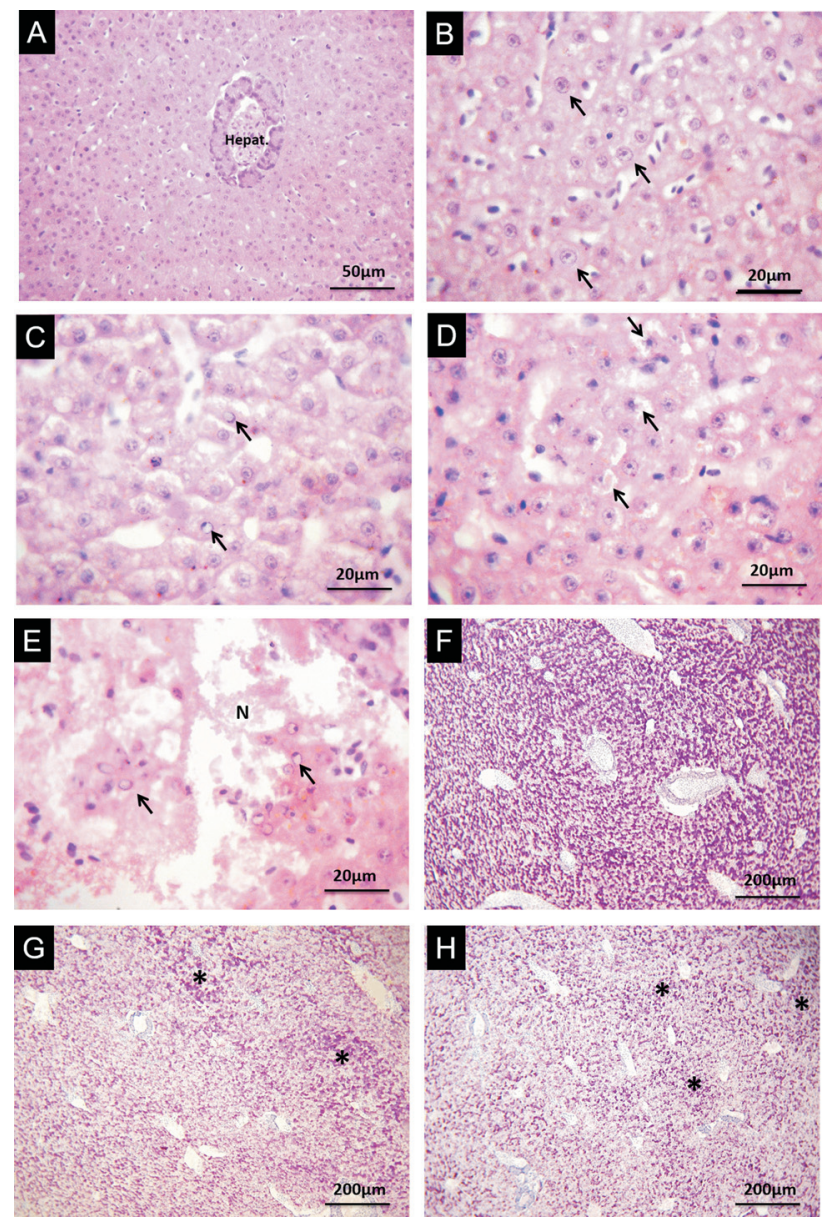

Figure 4 - Liver histopathology of C. macropomum in the three experimental groups: Group Without Injection (GWI); Group with corn oil injection (Sham); and Group with naphthalene injection (Naph) after $96 \mathrm{~h}$ normoxia exposure followed by $6 \mathrm{~h}$ of hypoxia. (A) normal $C$. macropomum liver standing out the hepatopancreas. (B, C) after Naph injection in normoxia. Arrows indicate nuclei hypertrophy (B) and nuclei vacuolization (C). (D, E) after Naph injection and subsequent hypoxia exposure. Arrows indicate hepatocytes with nuclei degeneration (D) and nuclei vacuolization (E); $\mathrm{N}$ shows focal necrosis. Hematoxylin and eosin stain. (F) C. macropomum liver of the Sham group in normoxia demonstrating a strong positive reaction to PAS. $(\mathrm{G}, \mathrm{H})$ C. macropomum liver after hypoxia exposure: GWI $(\mathrm{G})$ and Naph groups $(\mathrm{H})$ demonstrating a weak reaction to PAS. Asterisks indicate areas with higher glycogen concentration. PAS corresponds to Periodic Acid Schiff Stain.
Naph in normoxia. Nuclear vacuolation, classified as stage II damage, ranged from frequent to highly frequent in the Naph group in normoxia (Figure 4C) and all treatments in hypoxia (Figure 4E). Nuclear degeneration showed low frequency in fish treated with Naph under hypoxic conditions (Figure 4D). Necrotic foci were rare or had a low frequency in fish of all treatments, except for fish injected with naphthalene and subsequently exposed to hypoxia, where focal necrosis was a common lesion (Figure 4E).

Hepatocytes of C. macropomum kept under normoxia and hypoxia reacted differently to PAS. Under normal oxygen conditions, hepatocytes from the GWI and Sham showed a strong positive reaction to PAS (Figure 4F), which demonstrates a vast reserve of glycogen. In the group injected with Naph, this response ranged from moderate to strong. Hepatocytes of fish kept under hypoxia showed a decrease in glycogen in all three treatments (Figure 4G, H), represented by a reaction that ranged from mild to moderate when compared to fish kept under normoxia.

\section{tp53 expression}

Gene expression was influenced by the combination of low oxygen concentration $(p<0.001 ; \mathrm{F}=53.935)$ and Naph injection $(p<0.001 ; \mathrm{F}=34.470)$ (Figure 5). There was no interaction between factors $(p=0.369 ; \mathrm{F}=1.047)$. In fish contaminated with Naph, there was an increase in $t p 53$ mRNA levels in both normoxia and hypoxia compared to the GWI and Sham groups $(p<0.001)$. In normoxia, tp53 expression increased nearly 2.0 and 2.5 fold in fish after Naph injection compared to GWI and Sham, respectively. In fish exposed to hypoxia after contamination, tp53 mRNA levels were about 5 fold higher than in the GWI group and 8 fold higher than in the Sham group. There were no differences in tp53 mRNA levels between GWI and Sham in both normoxia and hypoxia groups. In fish exposed to hypoxia, gene expression was down-regulated compared to fish kept under normoxia $(p<0.001)$. However, fish contaminated with Naph and subsequently submitted to hypoxia maintained high mRNA levels when compared to groups without injection and injected with corn oil (GWI, and Sham), respectively (Figure 5).

\section{Multivariate analysis}

Principal component analysis (PCA) shows that the clustering of the different variables was mainly determined by oxygen concentration (normoxia and hypoxia) (Figure 6 ). The components $\mathrm{p} 1$ and $\mathrm{p} 2$ explained $74 \%$ of the original data variance $(\mathrm{p} 1=50 \%$ and $\mathrm{p} 2=24 \%)$. Normoxia and hypoxia were clustered in opposite quadrants as well as the GWI and Sham were clustered in the quadrant opposite to the Naph group. Variables are distributed in four clusters (Figure 6). One of the groups demonstrated the influence of hypoxia, represented by the clustering of variables $\mathrm{Hb}$, Hct, glucose and RBC, which increased in fish kept in hypoxia, whereas, normoxia explains the values of $\mathrm{MCHC}, \mathrm{MCH}$ 
Table 2 - Qualitative distribution of histopathological damage and occurrence intensity $(0$ absent, $0+$ rarely present, + low frequency, ++ frequent and +++ high frequency) on the liver of C. macropomum in the groups without injection (GWI), with corn oil injection (Sham) and naphthalene injection (Naph) after $96 \mathrm{~h}$ normoxia exposure followed by $6 \mathrm{~h}$ of hypoxia.

\begin{tabular}{|c|c|c|c|c|c|c|c|}
\hline \multirow[t]{2}{*}{ Lesion Type } & \multicolumn{4}{|c|}{ Normoxia } & \multicolumn{3}{|c|}{ Hypoxia } \\
\hline & Stage & GWI & Sham & Naph & GWI & Sham & Naph \\
\hline Nuclei hypertrophy & I & ++ & $0+$ & ++ & +++ & ++ & ++ \\
\hline Cell hypertrophy & I & $0+$ & $0+$ & $0+$ & $0+$ & $0+$ & $0+$ \\
\hline Nuclei in cell periphery & I & ++ & ++ & ++ & ++ & ++ & ++ \\
\hline Cytoplasm vacuolization & I & $0+$ & $0+$ & $0+$ & $0+$ & ++ & ++ \\
\hline Leukocyte infiltration & I & $0+$ & 0 & $0+$ & $0+$ & $0+$ & $0+$ \\
\hline Sinusoid dilation & I & ++ & +++ & +++ & +++ & +++ & +++ \\
\hline Cellular deformation & I & ++ & ++ & ++ & ++ & ++ & ++ \\
\hline Derangement of hepatic cords & I & 0 & 0 & $0+$ & 0 & 0 & 0 \\
\hline Vessel congestion & II & ++ & ++ & ++ & ++ & ++ & ++ \\
\hline Nuclei vacuolization & II & $0+$ & $0+$ & +++ & +++ & ++ & ++ \\
\hline Nuclei degeneration & II & $0+$ & $0+$ & $0+$ & $0+$ & $0+$ & ++ \\
\hline Cytoplasm degeneration & II & ++ & ++ & ++ & ++ & ++ & ++ \\
\hline Pyknotic nuclei & II & $0+$ & $0+$ & $0+$ & $0+$ & $0+$ & $0+$ \\
\hline Cell disruption & II & $0+$ & ++ & ++ & ++ & ++ & ++ \\
\hline Focal necrosis & III & $0+$ & ++ & ++ & ++ & $0+$ & ++ \\
\hline
\end{tabular}

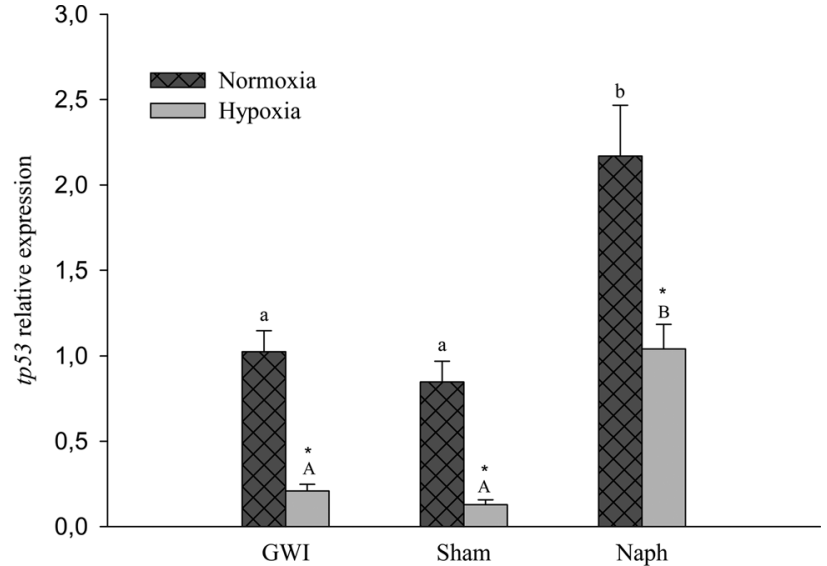

Figure 5 - Relative tp53 gene expression in C. macropomum liver in the the three experimental groups: Group Without Injection (GWI); Group with corn oil injection (Sham); and Group with naphthalene injection (Naph) after $96 \mathrm{~h}$ normoxia exposure followed by $6 \mathrm{~h}$ of hypoxia. Small cap letters $(\mathrm{a}$ and $\mathrm{b})$ indicate differences among treatments in normoxia. Capital letters (A and B) indicate differences among treatments in hypoxia. *Indicates differences between normoxia and hypoxia of the same treatment $(p<0.05)$.

and tp53 expression. The group without injection (GWI) explained the GST, CAT and MCV variables. Higher Naph influence occurred on the DNA damage index, LPO and, to a lesser extent, on the tp53 expression (Figure 6).

\section{Discussion}

In the present study, Naph did not influence $\mathrm{PO}_{2}$ crit in C. macropomum. The values found in this study are similar to those reported by Silva et al. (2019), where the mean values of $\mathrm{PO}_{2}$ crit were about $1.5 \mathrm{mg} \mathrm{O} \mathrm{L}^{-1}$. The authors also did not observe differences in the $\mathrm{PO}_{2}$ crit of $C$. macropoтиm exposed to the herbicide Roundup ${ }^{\circledR}$. However, Saint-Paul (1984) determined a $\mathrm{PO}_{2}$ crit of about $2 \mathrm{mg}$ $\mathrm{O}_{2} \mathrm{~L}^{-1}$ for C. macropomum. Lower values of $\mathrm{PO}_{2}$ crit indicate a higher tolerance to hypoxia and guarantee the supply of oxygen to tissues (Scott et al., 2008; De Boeck et al., 2013; Campos et al., 2016). Differences in $\mathrm{PO}_{2}$ crit can occur between congeneric species (Campos et al., 2016), inter-individual between fish of different sizes (Scott et al., 2008). This difference can also occur in fish exposed to food deprivation (De Boeck et al., 2013) and different times of acclimatization to hypoxia (Regan and Richards, 2017). In the present study, data for $\mathrm{PO}_{2}$ crit demonstrate that intraperitoneally injected Naph did not affect oxygen consumption in C. macropomum.

Similarly, the absence of a Naph effect, both in normoxia and hypoxia, was reflected in hematological parameters, which were affected exclusively by the variation in oxygen concentration (Table 1). In situations where oxygen supply to tissues is impaired, one of the responses seen in fish is hematological adjustment to improve uptake and transport oxygen to tissues (Val and Almeida-Val, 1995). This response was observed only in fish exposed to hypoxia, but not in fish injected with Naph, providing support to the idea that the intraperitoneal Naph injection probably did not affect oxygen consumption in C. macropomum. Gesto et al. (2008) also did not verify changes in plasma glucose levels after Naph injection followed by acute stress stimuli in Oncorhynchus mykiss. Similarly, the exposure of $C$. macropomum to crude oil from the Urucu Reserve (Amazonas, Brazil) in normoxia did not result in changes in 


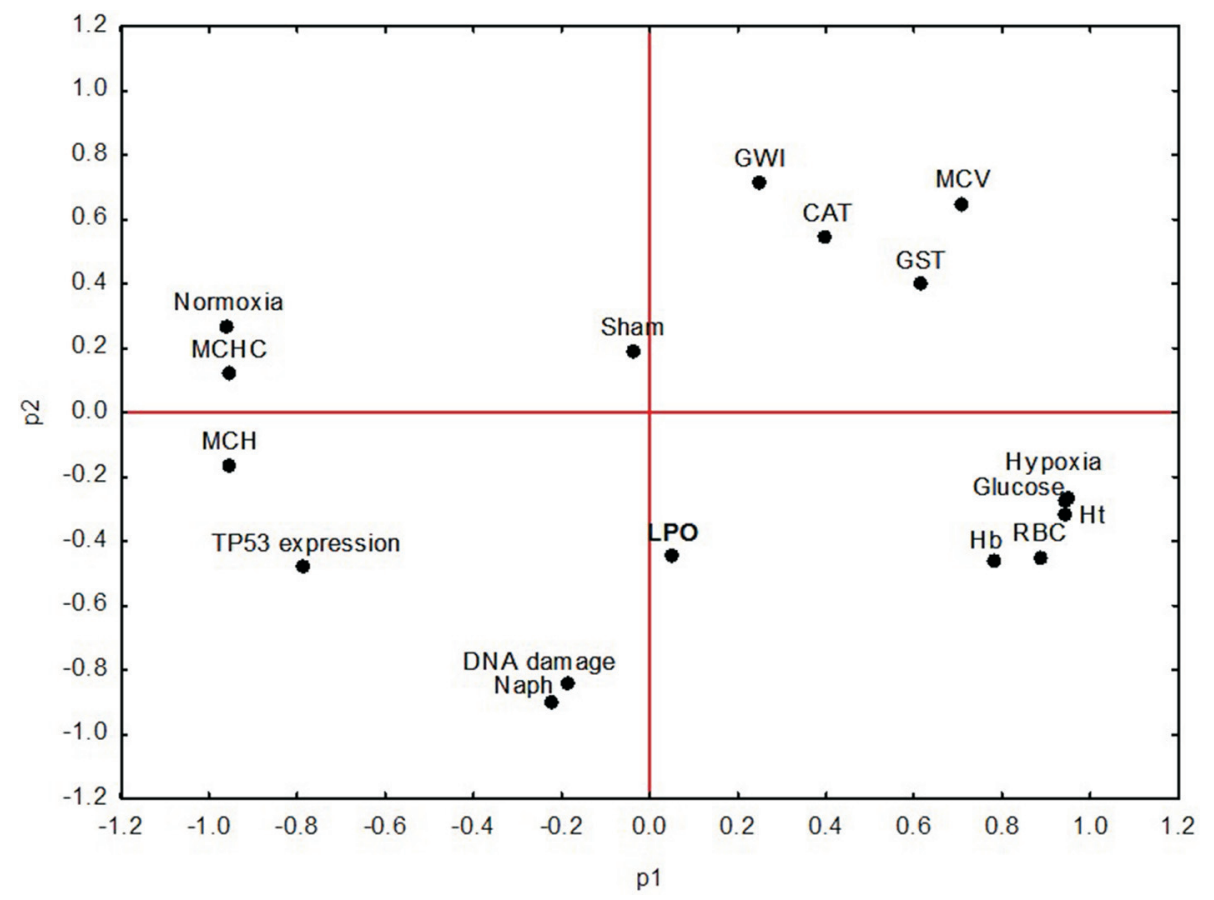

Figure 6 - Biplot representing the distribution of PCA values for the variables analyzed in C. macropomum in the three experimental groups: Group Without Injection (GWI); Group with corn oil injection (Sham); and Group with naphthalene injection (Naph) after $96 \mathrm{~h}$ normoxia exposure followed by $6 \mathrm{~h}$ of hypoxia. All groups are compared and variation among variables is explained by $\mathrm{p} 1=50.0 \%$ and $\mathrm{p} 2=24.0 \%$.

hematological parameters (Duarte et al., 2010; Kochhann et al., 2013).

Instead, hypoxia exposure resulted in changes in hematology (Table 1). The greater influence of oxygen concentration on hematology is supported by the PCA result, as demonstrated by the clustering of hematological variables determined by oxygen concentration (Figure 6). Hematological changes in Amazonian fish exposed to hypoxia are well reported in the literature (Val and Almeida-Val, 1995; Val, 1996; Baptista et al., 2016). The increase in plasma glucose levels suggests the use of glucose as an anaerobic energy source (Chippari-Gomes et al., 2005; Almeida-Val et al., 2006; Baptista et al., 2016). Herein, we suggest the occurrence of hepatic glycogenolysis, as demonstrated by Chippari-Gomes et al. (2005) in Astronotus crassipinnis, since the fish kept in hypoxia after the three treatments showed lower reactivity to PAS (Figure 4G and $\mathrm{H}$ ), revealing a decrease in hepatic glycogen amount.

Only Naph injection or Naph injection followed by hypoxia influenced the biotransformation and antioxidant defenses as demonstrated by GST and CAT enzymatic activities in the present study. Other studies demonstrated that exposure of C. macropomum to crude oil and $\mathrm{BaP}$ resulted in increased GST activity (Kochhann et al., 2013; Sadauskas-Henrique et al., 2016). However, in the present study, C. macropomum injected with Naph showed a reduction in GST activity when compared to GWI and Sham in normoxia (Figure 2A). This response can be the result of an increase in hepatic lesions, such as nuclei vacuolization, which was highly frequent, possibly leading to a decrease in liver function that could not be compensated for by increased nuclei hypertrophy, which was a recurrent lesion. A decline in GST activity was also verified by Palanikumar et al. (2013) after exposure of Chanos chanos to Naph, administered directly in the water. Simultaneous exposure of Cyprinodon variegatus larvae to chemically enhanced water accommodated fractions (CEWAFs) and hypoxia induced the reduction in GST activity compared to the same group in normoxia (Dasgupta et al., 2016). Results of the present study differ from the above described, suggesting that initial Naph injection and subsequent hypoxia exposure improved enzyme performance. Silva et al. (2019) also observed an increase in GST activity in C. macropomum contaminated with the herbicide Roundup ${ }^{\circledR}$ and subsequently exposed to hypoxia, when compared to the same group in normoxia. As exposure to hypoxia increases histopathological damages, including tissue necrosis, the increase in enzyme activity may be an attempt to minimize the damage resulting from the combination of hypoxia and Naph.

CAT activity presented the same response of GST (Figure 2B). In other studies, no differences were observed in CAT activity in C. macropomum after exposure to crude oil and BaP (Kochhann et al., 2013; Saudaskas-Henrique et al., 2016). Conversely, other authors have reported a reduction in this enzyme activity after fish exposure to the water-soluble fraction of diesel oil and small Naph concentrations (Zhang et al., 2004; Palanikumar et al., 2013). 
Dasgupta et al. (2016) also demonstrated that exposure of Cyprinodon variegatus larvae to CEWAFs induced the reduction in CAT in normoxia. Some authors report on the role of hypoxia or anoxia in the activation of antioxidant defenses and the induction of oxidative stress (Lushchak et al., 2001; Lushchak and Bagnyukova, 2007; Mustafa et al., 2011). However, in the present study, hypoxia per se did not influence CAT activity, as observed in the GWI and Sham. In the present study, the exposure of C. macropomum to reduced oxygen levels did not affect the activity of the antioxidant defenses as observed in other fish species (Lushchak et al., 2001; Lushchak and Bagnyukova, 2007). However, the Naph injection with subsequent hypoxia exposure appears to have improved CAT performance. Similar to what happened with GST activity, this increase in CAT activity may be a way to minimize the damage caused by exposure to Naph plus hypoxia. Silva et al. (2019) demonstrated an increase in CAT activity in fish exposed to Roundup $^{\circledR}$ and subsequently exposed to hypoxia, which was accompanied by increased histopathological damage in the liver.

No differences were observed in liver LPO in $C$. macropomum between treatments in both fish groups under normoxia or hypoxia, contrasting with the results of Palanikumar et al. (2013), who observed changes in LPO concentration after exposure of Chanos chanos to Naph, administered directly in water. However, Kochhann et al. (2013) did not find differences in lipid peroxidation in $C$. macropomum exposed to crude oil and neither did Dasgupta et al. (2016) observe variation in LPO after the simultaneous exposure of Cyprinodon variegatus larvae to CEWAFs plus normoxia or hypoxia. Silva et al. (2019) verified that there was no difference in the LPO in C. $m a-$ cropomum under hypoxic conditions, and in fish exposed to the herbicide Roundup ${ }^{\circledR}$ plus hypoxia there was a reduction in LPO.

Fish contaminated with Naph showed an increase in the DNA damage index in blood cells when kept in normoxia or exposed to hypoxia (Figure 3). Other studies have reported similar genetic damage in fish exposed to crude oil and PAHs, without, however, evaluating exposure to abiotic factors such as hypoxia (Kochhann et al., 2013; Palanikumar et al., 2013; Sadauskas-Henrique et al., 2016; Silva et al., 2017). The observed DNA damage in the present study caused by Naph in fish kept under normal oxygen conditions may be the result of the biotransformation process and antioxidant defenses that were inefficient, as demonstrated by the inhibition of the GST and CAT enzymatic activities, which have contributed to the increase of class 2 damage. Previous studies support this idea, as they show that the genotoxicity of Naph results from the inhibition of detoxification mechanisms (Teles et al., 2003; Palanikumar et al., 2013).

Hypoxia, independently, did not induce genotoxic damage in C. macropomum blood cells, which was corrob- orated by PCA, differing from previous studies (Mustafa $e t$ al., 2011; Negreiros et al., 2011). Just as we observed herein, Dasgupta et al. (2016) also demonstrated that hypoxia per se did not induce DNA damage in larvae of Cyprinodon variegatus. However, hypoxia is considered a factor that enhances DNA damage in fish exposed to both chemical and physical stressors (Groff et al., 2010; Mustafa et al., 2011, 2012; Negreiros et al., 2011; Dasgupta et al., 2016; Silva et al., 2019). In the present study, hypoxia exposure did not magnify genotoxic damages in fish previously contaminated with Naph, and the observed injuries were caused exclusively by Naph (Figure 3). Silva et al. (2019) also demonstrated that the exposure of C. macropomum to Roundup ${ }^{\circledR}$ and subsequent submission to hypoxia did not affect or magnify DNA damages. However, the hisptopatological response was different.

Many authors report histopathological liver damages in fish exposed to crude oil or derivatives (Akaishi et al., 2004; Gusmão et al., 2012; Silva et al., 2017). Herein, most of the alterations showed low to moderate frequencies (Table 2). Naph injection in normoxia resulted, as expected, increased nuclei hypertrophy, cell deformation, and nuclei vacuolation frequencies (Figure 4B, C). Exposure of $C$. macropomum to $\mathrm{BaP}$ via intraperitoneal injection also resulted in hepatic lesions that were even more severe than those observed in the present study (Silva et al., 2017), perhaps because $\mathrm{BaP}$ is considered to be more toxic than Naph. Liver histopathological damage was reported for Astyanax sp. (Akaishi et al., 2004) and Odontesthes argentinensis (Gusmão et al., 2012) exposed to the water-soluble fraction of crude oil. Omar-Ali et al. (2015) also demonstrated the occurrence of hepatic lesions in Atractosteus spatula exposed to the water-accommodated fraction of crude oil. In the present work, subsequent hypoxia exposure also induced a higher intensity in liver histopathological damages (Figure 4D and E) in all treatments. Although necrotic foci were present in all treatments, their frequency was low and punctually localized, except for fish contaminated with Naph and subsequently exposed to hypoxia, where necrosis was frequent and widely distributed, causing disorder in the analyzed tissue (Figure 4E). Silva et al. (2019) demonstrated that hypoxia induced and accentuated hepatic lesions in C. macropomum after exposure to the herbicide Roundup $^{\circledR}$, increasing, mainly, foci of necrosis. Mustafa et al. (2012) also reported that hypoxia induced hepatic damage in Cyprinus carpio after simultaneous exposure to copper. In this wok, the hepatic lesions occurred in fish exposed to Naph plus hypoxia, even without increasing LPO content, which was also observed by Silva et al. (2019). Due to the increase in liver damage of fish exposed to Naph and hypoxia, there is an attempt to minimize the negative effects of the combination of the stressors, through an increase in GST and CAT activity, as observed in this work.

Regarding the expression of the tumor suppressor gene tp 53 in fish from the Naph group in both normoxic and 
hypoxic conditions (Figure 5), the increase in gene expression was probably related to the histopathological damages resulting from Naph exposure, thus avoiding that the negative effects of Naph be passed on. Naph, as well as other PAHs, are considered genotoxic, promoting DNA damage in different tissues, such as liver, gills, and blood (Teles et al., 2003; Palanikumar et al., 2013, Sadaukas-Henrique et al., 2017). Increased p53 protein levels after exposure to DNA damaging agents have been reported for mammals (Kastan et al., 1991; Park et al., 2006). In fish, genotoxic xenobiotics exposure is accompanied by an increase in $t p 53$ mRNA levels (Mai et al., 2012). Increased histopathological damage, observed in this study, might have modulated the expression of tp 53, inducing a cell cycle block that prevents possible damage from being passed on to new cells, as an attempt to avoid aggravation of the hepatic lesion. A study by Tu et al. (2016) demonstrated that the exposure of the tp53 null mutant strain Oryzias latipes to propiconazole resulted in increased hepatic lesions when compared to wild-type fish, presenting even greater susceptibility to hepatocarcinogenesis. An increase in tp 53 transcripts was also observed in fish exposed to heavy fuel oil (Ruiz et al., 2012) and in fish captured at contaminated sites (Williams and Hubberstey, 2014), without, however, considering the effect of hypoxia exposure.

Hypoxia is also a factor related to the regulation of the gene $t p 53$. However, studies on the role of hypoxia in the regulation of this gene have been mostly performed in mammalian cells under in vitro conditions, and these report controversial results, such as accumulation (Koumenis et al., 2001; Hammond et al., 2002), or decrease in p53 protein levels (Cosse et al., 2009; Chen et al., 2010). Studies on the effects of hypoxia on $t p 53$ gene expression in fish are scarce to date and, for the best of our knowledge, this is the first study that evaluates this gene expression in an Amazonian fish species under the effects of hypoxia after a PAH injection. The role of hypoxia in $t p 53$ gene regulation in the present study was more intense than that of Naph injection, as shown by the $\mathrm{F}$ values for oxygen concentration (53.935) and treatments (34.470) and after the PCA analysis (Figure 6). Although hypoxia induced the decrease of tp53 transcripts in all treatments, in fish injected with naphthalene there was a clear attempt to maintain the response similar to group in normoxia, with increased transcription of the gene. A similar response, to minimize damage resulting from the combination of Naph and hypoxia was also observed in the activity of the GST and CAT enzymes. However, in fish treated with Naph in normoxia, this increase in the number of transcripts was about 2 fold greater than in the same group in hypoxia. The lower efficiency to activate tp53 gene transcription could have occurred due to the combination between increased nuclei vacuolation and focal necrosis intensity, which may have resulted in the reduction of functional hepatocytes, thus compromising organ function.
In mammalian cells, hypoxia exposure did not change tp53 mRNA levels (Koumenis et al., 2001; Chen et al., 2010), differing from the results of the present study, indicating that the destruction of tissue and effects on hepatocytes were more severe when we used fish as model and in vivo experiments. These responses suggest that, unlike the previously proposed genotoxic effects for contamination with xenobiotics such as naphthalene, hypoxia promotes a differential regulation of tp53 expression, and differs between animal models (mammals) and experimental biological types (whole live fish and isolated live cells). Recent studies with white shrimp (Litopenaeus vannamei) have shown that hypoxia affects the transcription of tp53. Nuñez-Hernandez et al. (2018) demonstrated that exposure of $L$. vannamei to $48 \mathrm{~h}$ of hypoxia resulted in increased tp 53 transcript levels in the hepatopancreas. Controversial results have been reported by Felix-Portillo et al. (2016), who demonstrated that $48 \mathrm{~h}$ of exposure to hypoxia resulted in a reduction in tp53 transcripts in hemocytes. Time of exposure to hypoxia may explain these diferences, since hypoxia induces metabolic depression in some animals (Almeida-Val et al., 2000).

Further studies need to be performed for a better understanding of the effects of hypoxia on the regulation of tp53 gene expression and p53 protein levels in fish. Moreover, one should consider that the in vivo responses of the organism to hypoxia are much more complex than the responses of cells in vitro, particularly when the model is Amazonian fish that, due to the seasonal and daily variations in the dissolved oxygen concentration, have developed adaptations to survive long and intermittent periods of oxygen shortage (Val and Almeida-Val, 1995). The decrease in tp53 gene expression in GWI and Sham after hypoxia exposure might be related to metabolic depression plus the increased frequency of hepatic lesions. Nuclei vacuolization is considered a sign of a degenerative process that reduces metabolically active areas of the liver, resulting in a decrease in hepatic functions (Pacheco and Santos, 2002; Camargo and Martinez, 2007; Benze et al., 2014). Fish under these circumstances may not be able to compensate for these lesions, even though there was a significant occurrence of nuclei hypertrophy, demonstrating a tentative increase in cell activity (Benze et al., 2014).

\section{Conclusion}

Hypoxia accentuated the harmful effects of naphthalene injection, with the exception of hematological and genotoxicity (comet assay) parameters. Naph and hypoxia had an opposite effect on tp53 tumor suppressor gene regulation. The tp53 down-regulation seen in hypoxic fish differs from that occurring in mammalian cells and, in the present study, it might be related to metabolic depression mechanisms in these fish, plus the observed higher intensity of hepatic lesions. For a better comparison of studies between mammalian and fish cells, hepatocyte cultures 
should be used for comparative analyses at the $\mathrm{p} 53$ protein level. The increase in tp53 mRNA levels, as well as the increase in GST and CAT activities in fish treated with Naph and subsequently exposed to hypoxia, provides clear evidence that, even under low oxygen conditions, individuals of $C$. macropomum, injected with genotoxic agents, invest in the defense of liver cells. Thus, given the aquatic contamination, this species increased, preferentially, the tp 53 gene transcription, as an attempt to ensure the maintenance of genomic integrity, but this was not as efficient as in fish kept in normoxia, demonstrating that responses at the transcriptional level of the tp53 gene in fish may be compromised by hypoxia. This response reflects the importance of considering hypoxia as an additional risk factor for aquatic contamination, especially in an environment where hypoxic conditions occur both daily and seasonally, besides being a parameter that contributes to the development and greater severity of cancer.

\section{Acknowledgments}

This work was funded in part by the Coordenação de Aperfeiçoamento de Pessoal de Nível Superior - Brasil (CAPES) - Finance Code 001 - Project number: 23038.000736/2013-89, that supported the Project Tambaqui (Edital Pro Amazonia - 047/2012). We also thank INCT ADAPTA supported by CNPq and FAPEAM. SSS was the recipient of a MSc. Fellowship from FAPEAM, and VMFAV is the recipient of a Research Fellowship from CNPq. We thank Lorena Matos for her assistance with the histopathological analysis, and Waldir Heinrichs Caldas for his assistance with $\mathrm{PO}_{2}$ crit analysis. Thanks are also due to the personnel of the Thematic Laboratory of Microscopy Optics and Electronics (LTMOE) from INPA and Functional Histology Laboratory from UFAM for their support with the preparation of histological material.

\section{Conflict of interest}

The authors have no conflicts of interest to declare.

\section{Author contributions}

SSS, GSS and VMFAV conceived and designed the study; SSS conducted the experiments, analyzed the data and wrote the manuscript; GSS was involved in the design, experimental execution and reviewed the manuscript draft; VMFAV supervised this study, discussed and revised the manuscript. All authors read and approved the final version.

\section{References}

Akaishi FM, Silva de Assis HC, Jakobi CG, Eiras-Stofella DR, St-Jean SD, Courtenay SC, Lima EF, Wagener ALR, Scofield AL and Oliveira Ribeiro CA (2004) Morphological and neurotoxicological findings in tropical freshwater fish (Astyanax sp.) after waterborne and acute exposure to water solu- ble fraction (WSF) of crude oil. Arch Environ Contam Toxicol 46:244-253.

Almeida-Val VMF, Val AL, Duncan WP, Souza FCA, PaulaSilva NM and Land S (2000) Scaling effects of hypoxia tolerance in the Amazon fish Astronotus ocellatus (Perciformes: Cichlidae): contribution of tissue enzyme levels. Comp Biochem Physiol B Biochem Mol Biol 125:219-226.

Almeida-Val VMF, Chippari-Gomes AR and Lopes NP (2006) Metabolic and physiological adjustments to low oxygen and high temperature in fishes of the Amazon. In: Val AL, Almeida-Val VMF and Randall DJ (eds) Fish Physiology. Elsevier, Heidelberg, pp 443-500.

Baptista RB, Souza-Castro N and Almeida-Val VMF (2016) Acute hypoxia up-regulates HIF-1a and VEGF mRNA levels in Amazon hypoxia-tolerant Oscar (Astronotus ocellatus). Fish Physiol Biochem 42:1307-1318.

Benze TP, Sakuragui MM, Zago LHP and Fernandes MN (2014) Subchronic exposure to diflubenzuron causes health disorders in neotropical freshwater fish, Prochilodus lineatus. Environ Toxicol 32:533-542.

Berghmans S, Murphey RD, Wienholds E, Neuberg D, Kutok JL, Fletcher CDM, Morris JP, Liu TX, Schulte-Merker S, Kanki JP et al. (2005) tp53 mutant zebrafish develop malignant peripheral nerve sheath tumors. Proc Natl Acad Sci U S A 102:407-412.

Beutler E (1975) Red cell metabolism: A manual of biochemical methods. 2nd edition. Grune \& Stratton, New York, 146 p.

Bradford MM (1976) A rapid and sensitive method for the quantitation microgram quantities of protein utilizing the principle of protein-dye binding. Anal Biochem 72:248-254.

Brown BA (1976) Hematology: Principles and Procedures. 2nd edition. Lea \& Feibiger, Philadelphia, 336 p.

Camargo MMP and Martinez CBR (2007) Histopathology of gills, kidney and liver of a Neotropical fish caged in na urban stream. Neotrop Ichthyol 5:327-336.

Campos DF, Jesus TF, Kochhann D, Heinrichs-Caldas W, Coelho MM and Almeida-Val VMF (2016) Metabolic rate and thermal tolerance in two congeneric Amazon fishes: Paracheirodon axelrodi Schultz, 1956 and Paracheirodon simulans Géry, 1963 (Characidae). Hydrobiologia 1:133-142.

Chen B, Longtine MS, Sadovsky Y and Nelson DM (2010) Hypoxia downregulates p53 but induces apoptosis and enhances expression of BAD in cultures of human syncytiotrophoblasts. Am J Physiol Cell Physiol 299:C968-C976.

Chippari-Gomes AR, Gomes LC, Lopes NP, Val AL and Almeida-Val VMF (2005) Metabolic adjustments in two Amazonian cichlids exposed to hypoxia and anoxia. Comp Biochem Physiol B Biochem Mol Biol 141:347-355.

Cosse JP, Ronvaux M, Ninane N, Raes MJ and Michiels C (2009) Hypoxia-induced decrease in $\mathrm{p} 53$ protein level and increase in c-jun DNA binding activity results in cancer cell resistance to etoposide. Neoplasia 11:976-986.

Dasgupta S, DiGiulio RT, Drollette BD, Plata DL, Brownawell BJ and McElroy AE (2016) Hypoxia depresses CYP1A induction and enhances DNA damage, but has minimal effects on antioxidant responses in sheepshead minnow (Cyprinodon variegatus) larvae exposed to dispersed crude oil. Aquat Toxicol 177:250-260.

De Boeck G, Wood CM, Iftikar FI, Matey V, Scott GR, Sloman KA, Paula-Silva MN, Almeida-Val VMF and Val AL (2013) Interactions between hypoxia tolerance and food de- 
privation in Amazonian oscars, Astronotus ocellatus. J Exp Biol 216:4590-4600.

Donehower LA, Harvey M, Slagle BL, McArthur MJ, Montgomery CA, Butel JS and Bradley A (1992) Mice deficient for p53 are developmentally normal but susceptible to spontaneous tumours. Nature 356:215-221.

Duarte RM, Honda RT and Val AL (2010) Acute effects of chemically dispersed crude oil on gill ion regulation, plasma ion levels and haematological parameters in tambaqui (Colossoma macropomum). Aquat Toxicol 97:134-141.

Eales KL, Hollinshead KEK and Tennant DA (2016) Hypoxia and metabolic adaptation of cancer cells. Oncogenesis 5:1-8.

Felix-Portillo M, Martínez-Quintana JA, Arenas-Padilla M, Mata-Haro V, Gómez-Jiménez S and Yepiz-Plascencia G (2016) Hypoxia drives apoptosis independently of p53 and metallothionein transcript levels in hemocytes of the whiteleg shrimp Litopenaeus vannamei. Chemosphere 161:454-462.

Gesto M, Soengas JL and Míguez JM (2008) Acute and prolonged stress responses of brain monoaminergic activity and plasma cortisol levels in rainbow trout are modified by PAHs (naphthalene, $\beta$-naphthoflavone and benzo $(a)$ pyrene) treatment. Aquat Toxicol 86:341-351.

Gesto M, Tintos A, Rodríguez-Illamola A, Soengas JL and Míguez JM (2009) Effects of naphthalene, $\beta$-naphthoflavone and benzo(a)pyrene on the diurnal and nocturnal indoleamine metabolism and melatonina content in the pineal organ of rainbow trout, Oncorhynchus mykiss. Aquat Toxicol 92:1-8.

Goldenfarb PB, Bowyer FP and Hall E (1971) Reproducibility in the hematology laboratory: The microhematocrit determination. Am J Clin Pathol 56:35-39.

Gusmão EP, Rodrigues RV, Moreira CB, Romano LA, Sampaio LA and Miranda-Filho KC (2012) Growth and histopathological effects of chronic exposition of marine pejerrey Odontesthes argentinensis larvae to petroleum water-soluble fraction (WSF). Ambio 41:456-466.

Groff AA, Silva J, Nunes EA, Ianistcki M, Guecheva TN, Oliveira AM, Oliveira CPF, Val AL and Henriques JAP (2010) UVA/UVB-induced genotoxicity and lesion repair in Colossoma macropomum and Arapaima gigas Amazonian fish. J Photochem Photobiol B Biol 99:93-99.

Hammond EM, Denko NC, Dorie MJ, Abraham RT and Giaccia AJ (2002) Hypoxia links ATR and p53 through replication arrest. Mol Cell Biol 22:1834-1843.

Jiang ZY, Hunt JV and Wolff SP (1992) Ferrous ion oxidation in the presence of xylenol orange for detection of lipid hydroperoxide in low density lipoprotein. Anal Biochem 202:384-389.

Junk WJ, Soares GM and Carvalho FM (1983) Distribution of fish species in a lake of the Amazon river floodplain near Manaus (Lago Camaleão), with special reference to extreme oxygen conditions. Amazoniana 6:397-431.

Kampen EJ and Zijlstra WG (1961) Standardization of hemoglobinometry II. The hemiglobincyanide method. Clin Chim Acta 6:538-544.

Kastan MB, Onyekwere O, Sidransky D, Vogelstein B and Craig RW (1991) Participation of p53 protein in the cellular response to DNA damage. Cancer Res 51:6304-6311.
Keen JH, Habig WH and Jakoby WB (1976) Mechanism for the several activities of the Glutathione S-Transferases. J Biol Chem 251:6188-1976.

Kobayashi H, Sugiyama C, Morikawa Y, Hayashi M and Sofundi $\mathrm{T}$ (1995) A comparison between manual microscopic analysis and computerized image analysis in the single cell gel electrophoresis assay. MMS Commun 3:103-115.

Kochhann D, Brust SMA, Domingos FXV and Val AL (2013) Linking hematological, biochemical, genotoxic, and behavioral responses to crude oil in the Amazon fish Colossoma macropomum (Cuvier, 1816). Arch Environ Contam Toxicol 65:266-275.

Kochhann D, Jardim MM, Domingos FXV and Val AL (2015) Biochemical and behavioral responses of the Amazonian fish Colossoma macropomum to crude oil: The effect of oil layer on water surface. Ecotoxicol Environ Saf 111: 32-41.

Koumenis C, Alarcón R, Hammond E, Sutphin P, Hoffman W, Murphy M, Derr J, Taya Y, Lowe SW, Kastan M and Giaccia A (2001) Regulation of p53 by hypoxia: Dissociation of transcriptional repression and apoptosis from $\mathrm{p} 53$ dependent transactivation. Mol Cell Biol 21:1297-1310.

Lee SLC, Rouhi P, Jensen LD, Zhang D, Ji H, Hauptmann G, Ingham P and Cao Y (2009) Hypoxia-induced pathological angiogenesis mediates tumor cell dissemination, invasion, and metastasis in a zebrafish tumor model. Proc Natl Acad Sci U S 46:9485-19490.

Livak KJ and Schmittgen TD (2001) Analysis of relative gene expression data using real-time quantitative PCR and the 2 (-Delta Delta C (T)) method. Methods 25:402-408.

Lushchak VI and Bagnyukova TV (2007) Hypoxia induces oxidative stress in tissues of a goby, the rotan Perccottus glenii. Comp Biochem Physiol B Biochem Mol Biol 148:390-397.

Lushchak VI, Lushchak LP, Mota AA and Hermes-Lima M (2001) Oxidative stress and antioxidant defenses in goldfish Carassius auratus during anoxia and reoxygenation. Am J Physiol Regul Integr Comp Physiol. 280:R100-R107.

Mai W, Liu P and Wang W (2012) Characterization of the tilapia p53 gene and its role in chemical-induced apoptosis. Biotechnol Lett 34:1797-1805.

Mustafa SA, Al-Subiai SN, Davies SJ and Jha AN (2011) Hypoxia-induced oxidative DNA damage links with higher level biological effects including specific growth rate in common carp, Cyprinus carpio L. Ecotoxicology 20:1455-1466.

Mustafa SA, Davies SJ and Jha AN (2012) Determination of hypoxia and dietary copper mediated sub-lethal toxicity in carp, Cyprinus carpio, at different levels of biological organization. Chemosphere 87:413-422.

Negreiros LA, Silva BF, Paulino MG, Fernandes MN and Chippari-Gomes AR (2011) Effects of hypoxia and petroleum on the genotoxic and morphological parameters of Hippocampus reidi. Comp Biochem Physiol C 153:408-414.

Nuñez-Hernandez DM, Felix-Portillo M, Peregrino-Uriarte AB and Yepiz-Plascencia G (2018) Cell cycle regulation and apoptosis mediated by $\mathrm{p} 53$ in response to hypoxia in hepatopancreas of the white shrimp Litopenaeus vannamei. Chemosphere 190:253-259.

Omar-Ali A, Hohn C, Allen PJ, Rodriguez J and Petrie-Hanson L (2015) Tissue PAH, blood cell and tissue changes following exposure to water accommodated fractions of crude oil in al- 
ligator gar, Atractosteus spatula. Mar Environ Res 108:3344.

Pacheco M and Santos MA (2002) Biotransformation, genotoxic, and histopathological effects of environmental contaminants in European eel (Anguilla anguilla L.). Ecotoxicol Environ Saf 53:331-347.

Palanikumar L, Kumaraguru AK and Ramakritinan CM (2013) Biochemical and genotoxic response of naphthalene to fingerlings of milkfish Chanos chanos. Ecotoxicology 22:1111-1122.

Park SY, Lee SM, Ye SK, Yoon SH, Chung MH and Choi J (2006) Benzo[a]pyrene-induced DNA damage and p53 modulation in human hepatoma HepG2 cells for the identification of potential biomarkers for PAH monitoring and risk assessment. Toxicol Lett 167:27-33.

Poleksic V and Mitrovic-Tutundic V (1994) Fish gills as a monitor of sublethal and chronic effects of pollution. In: Müller R and Lloyd R (eds) Sublethal and chronic effects of pollutants on freshwater fish. Fishing News Books, Oxford, pp 339352 .

Pörtner HO, Heisler N and Grieshaber MK (1985) Oxygen consumption and mode of energy production in the intertidal worm Sipunculus nudus L.: Definition and characterization of the critical $\mathrm{PO}_{2}$ for an oxyconformer. Respir Physiol 59:361-377.

Prado-Lima M and Val AL (2016) Transcriptomic characterization of Tambaqui (Colossoma macropomum, Cuvier, 1818) exposed to three climate change scenarios. PLoS One 11:e152366.

Regan MD and Richards JG (2017) Rates of hypoxia induction alter mechanisms of $\mathrm{O}_{2}$ uptake and the critical $\mathrm{O}_{2}$ tension of goldfish. J Exp Biol 220:2536-2544.

Ruiz P, Orbea A, Rotchell JM and Cajaraville MP (2012) Transcriptional responses of cancer-related genes in turbot Scophthalmus maximus and mussels Mytilus edulis exposed to heavy fuel oil no.6 and styrene. Ecotoxicology 21:820-831.

Sadauskas-Henrique H, Braz-Mota S, Duarte RM and AlmeidaVal VMF (2016) Influence of the natural Rio Negro water on the toxicological effects of a crude oil and its chemical dispersion to the Amazonian fish Colossoma macropomum. Environ Sci Pollut Res 23:19764-19775.

Sadauskas-Henrique H, Duarte RM, Gagnon MM and AlmeidaVal VMF (2017) Validation of a suite of biomarkers of fish health in the tropical bioindicator species, tambaqui ( $\mathrm{Co}$ lossoma macropomum). Ecol Indic 73:443-451.

Saint-Paul U (1984) Physiological adaptation to hypoxia of a neotropical characoid fish Colossoma macropomum, Serrasalmidae. Env Biol Fish 11:53-62.

Scott GR, Wood CM, Slomand KA, Iftikar FI, De Boeck G, Almeida-Val VMF and Val AL (2008) Respiratory responses to progressive hypoxia in the Amazonian oscar, Astronotus ocellatus. Respir Physiol Neurobiol 162:109-116.

Shi H, Sui Y, Wang X, Luo Y and Ji L (2005) Hydroxyl radical production and oxidative damage induced by cadmium and naphthalene in liver of Carassius auratus. Comp Biochem Physiol C 140:115-121.
Silva GA (2004) Alterações histopatológicas de peixes como biomarcadores da contaminação aquática Londrina. M. Sc. Thesis, Universidade Estadual de Londrina (UEL).

Silva GS, Fé LML, Paula-Silva MN and Almeida-Val VMF (2017) Ras oncogene and hypoxia-inducible factor-1 alpha (hif-1 $\alpha$ ) expression in Amazon fish Colossoma macropomum (Cuvier, 1818) exposed to benzo[a]pyrene. Genet Mol Biol 40:491-501.

Silva GS, Matos LV, Freitas JOS, Campos DF and Almeida-Val VMF (2019) Gene expression, genotoxicity, and physiological responses in an Amazonian fish, Colossoma macropomum (CUVIER, 1818), exposed to Roundup ${ }^{\circledR}$ and subsequent acute hypoxia. Comp Biochem Physiol C Toxicol Pharmacol 222:9-58.

Silva J, Freitas TRO, Marinho JR, Speit G and Erdtmann B (2000) An alkaline single-cell gel electrophoresis (comet) assay for environmental biomonitoring with native rodents. Genet Mol Biol 23:241-245.

Singh NP, McCoy MT, Tice RR and Schneider EL (1988) A Simple technique for quantitation of low levels of DNA damage in individual cells. Exp Cell Res 175:184-191.

Teles M, Pacheco M and Santos MA (2003) Anguilla anguilla L. liver ethoxyresorufin O-deethylation, glutathione S-tranferase, erythrocytic nuclear abnormalities, and endocrine responses to naphthalene and $\beta$-naphthoflavone. Ecotoxicol Environ Saf 55:98-107.

Tintos A, Gesto M, Míguez JM and Soengas JL (2007) Naphthalene treatment alters liver intermediary metabolism and levels of steroid hormones in plasma of rainbow trout $(\mathrm{On}$ corhynchus mykiss). Ecotoxicol Environ Saf 66:139-147.

Tu TY, Hong CY, Sasado T, Kashiwada S and Chen P (2016) Early life exposure to a rodent carcinogen propiconazole fungicide induces oxidative stress and hepatocarcinogenesis in medaka fish. Aquat Toxicol 170:52-61.

Val AL (1996) Surviving low oxygen levels: Lessons from fishes of the Amazon. In: Val AL, Almeida-Val VMF and Randall DJ (eds) Physiology and Biochemistry of the fishes of the Amazon. Instituto Nacional de Pesquisas da Amazônia, Manaus, pp 59-73.

Val AL and Almeida-Val VMF (1995) Fishes of the Amazon and their Environments. Physiological and Biochemical Aspects. Springer, Heidelberg, $224 \mathrm{p}$.

Van der Oost R, Beyer J and Vermeulen NPE (2003) Fish bioaccumulation and biomarkers in environmental risk assessment: A review. Environ Toxicol Pharmacol 13:57-149.

Vaupel P and Mayer A (2007) Hypoxia in cancer: Significance and impact on clinical outcome. Cancer Metastasis Rev 26:225-239.

Williams R and Hubberstey AV (2014) Benzo(a)pyrene exposure causes adaptive changes in p53 and CYP1A gene expression in Brown bullhead (Ameiurus nebulosus). Aquat Toxicol 156:201-210.

Zhang JF, Wang XR, Guo HY, Wu JC and Xue YQ (2004) Effects of water-soluble fractions of diesel oil on the antioxidant defenses of the goldfish, Carassius auratus. Ecotoxicol.Environ Saf 58:110-116.

Associate Editor: Igor Schneider

License information: This is an open-access article distributed under the terms of the Creative Commons Attribution License (type CC-BY), which permits unrestricted use, distribution and reproduction in any medium, provided the original article is properly cited. 